\title{
JOURNAL.RU
}

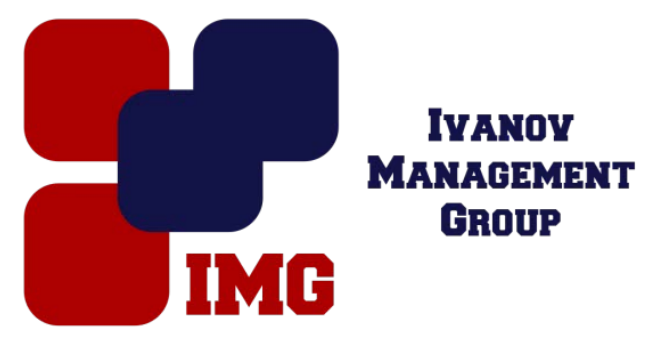

\author{
Хаврошина Ю.О., Захарченко М.Ю., Мельников И.Н., \\ Пичхидзе С.Я., Кайргалиев Д.В.
} Саратовский государственный технический университет им. Гагарина Ю.А.

Саратов, Россия

doi: 10.18411/lj-30-11-2016-4-12

idsp 000001:lj-30-11-2016-4-12

\section{Ингибиторы коррозии в огнетушащих составах}

\begin{abstract}
Аннотация
Рассмотрена возможность использования ингибиторов коррозии в огнетушащих составах.

Ключевые слова: антипирены, коррозия.

В последнее время для повышения эффективности тушения пожаров все чаще используются огнетушащие порошки - углекислая и двууглекислая сода, которые можно отнести к антипиренам [1]. Их подают в зону горения из огнетушителей сжатым воздухом. Данные огнетушащие порошки, на наш взгляд, также способствуют снижению температуры замерзания водных огнетушащих растворов и замедляют коррозию металлов, контактирующих с огнетушащим раствором. [2].

Данное предположение проверено нами на примере углекислой и двууглекислой соды.

Анализ полученных результатов свидетельствует, что использование 1 \%ных растворов указанных компонентов не снижает коррозионную стойкость металлов при их взаимодействии с огнетушащими составами.
\end{abstract}




\section{Литература}

1. Хаврошина Ю.О., Белоус Д.С. Разработка огнестойких составов для пропитки огнезащитных костюмов пожарных и спасателей. http://www.school-science.ru/2017/19/26192

2. Актуальные вопросы экспертизы веществ, материалов, изделий и перспективы её развития /И. Н. Мельников [и др.] //Комплексные проблемы техносферной безопасности: материалы Междунар. науч.-практ. конф. Ч. III. Воронеж, 2014. - С. 51-55. 